\title{
CHARACTERIZATION OF HUMAN T CELL CLONES SPECIFIC FOR CORONAVIRUS 229E
}

\author{
J. S. Spencer, ${ }^{1-3}$ G. F. Cabirac, ${ }^{1,2,4}$ C. Best, ${ }^{1}$ L. McLaughlin, ${ }^{1}$ and \\ R. S. Murray ${ }^{2,5}$ \\ ${ }^{1}$ Rocky Mountain Multiple Sclerosis Center \\ ${ }^{2}$ Colorado Neurological Institute \\ Englewood, Colorado \\ ${ }^{3}$ Department of Immunology \\ ${ }^{4}$ Department of Biochemistry, Biophysics and Genetics \\ University of Colorado Health Sciences Center \\ Denver, Colorado \\ ${ }^{5}$ National Jewish Center for Immunology and Respiratory Medicine \\ Denver, Colorado
}

\begin{abstract}
Coronaviruses $(\mathrm{CV})$ are pleomorphic enveloped RNA viruses that are ubiquitous in nature, causing a variety of diseases in both man and domestic animals. In man, CV are generally associated with upper respiratory tract infections. The two prototype strains that are the best studied human CV isolates and which are thought to be responsible for most of the respiratory infections caused by CV are called 229E and OC43. Humoral responses consisting of neutralizing antibodies to $\mathrm{CV}$ are present in most individuals by six years of age. Although the cellular immune response to CV in man has not been characterized at all, it is known that the spike (S) and nucleocapsid (N) proteins elicit the major cell mediated immune responses in the mouse.

This report describes the production and characterization of eleven independently isolated $\mathrm{T}$ cell clones that are specific for the human $\mathrm{CV}(\mathrm{HCV}) 229 \mathrm{E}$. The T cell clones are $\mathrm{CD}^{+}$and presumably recognize a processed viral peptide presented by class II molecules on the surface of antigen presenting cells. Of six 229E-specific T cell clones tested against purified viral proteins, three recognize the $180 \mathrm{kD}$ spike glycoprotein while the other three recognize the $55 \mathrm{kD}$ nucleocapsid phosphoprotein. Analysis of the human $\mathrm{T}$ cell mediated response to $\mathrm{HCV}$ will provide information regarding which viral proteins elicit the immunodominant response, what the fine specificity of these $\mathrm{T}$ cell clones are (immuno-dominant peptides), and what the T cell receptor (TCR) and cytokine usage is of these virus specific clones.
\end{abstract}




\section{INTRODUCTION}

Multiple sclerosis (MS) is a chronic demyelinating disease of the human central nervous system (CNS). The etiology of MS is unknown, although analysis of animal models of experimental allergic encephalomyelitis ${ }^{1-3}$ as well as data from MS patients (reviewed in Ref. 4) indicate that both genetic and environmental factors contribute to this disease. Viruses are among the environmental factors that have been proposed as possible causative agents for MS. Although numerous viral agents have been implicated as candidates in the etiology of MS, no clear association between any particular virus and the disease has been confirmed ${ }^{5}$.

Although CV infection in man is more frequently associated with upper respiratory tract infections, causing up to $35 \%$ of all cases of the common cold ${ }^{6,7}$, there is evidence that $\mathrm{CV}$ are also involved in enteric infections $\mathrm{s}^{8,9}$ and childhood meningitis ${ }^{10}$. In the latter case, a coronavirus (Tettnang virus) was cultured from the cerebrospinal fluid of an 18 month old child with viral meningitis that followed an upper respiratory tract infection. The possible involvement of CV in MS was suggested initially by the observation of viral particles bearing the typical morphological features of $\mathrm{CV}$ in electron microscopic sections of brain taken from an MS patient ${ }^{11}$, followed by a report describing the isolation of two separate $\mathrm{CV}$ from MS autopsy brain tissue ${ }^{12,13}$. Recently, our laboratory has identified murine-like coronavirus (MCV) RNA sequence and antigen in MS brain by in situ hybridization and immunohistochemical techniques ${ }^{14}$. Another group of investigators found human CV 229E sequences in MS brains by using the polymerase chain reaction ${ }^{15}$, and also showed that the virus may be neurotropic due to its ability to infect a variety of human cell lines of CNS origin ${ }^{16}$. Following intracranial inoculation, $\mathrm{CV}$ can productively infect and disseminate in primate brains, resulting in encephalomyelitis and demyelination ${ }^{17}$. Similarly, MCV infections in rodents result in a panencephalitis accompanied by extensive demyelination ${ }^{18,19}$. Rodents infected with subacute levels of MCV JHM show evidence of chronic demyelination as a result of viral persistence within the $\mathrm{CNS}^{20,21}$. In mice both $\mathrm{CD} 4^{+}$and $\mathrm{CD} 8^{+} \mathrm{T}$ cells are required for $\mathrm{CV}$ clearance from the CNS and for prevention of encephalomyelitis ${ }^{22,23}$. Because the pathological changes in the CNS observed in rodents infected with JHM resemble those found in MS patients, this animal model has been used extensively to study both acute and chronic forms of demyelinating disease caused by viruses. We have chosen to characterize the human cell mediated response to $229 \mathrm{E}$ to determine whether there may be any relationship between $\mathrm{CV}$ and multiple sclerosis.

\section{MATERIALS AND METHODS}

\section{Viruses and Cell Lines}

The HCV strain 229E was grown on the human lung fibroblast cell line, WI-38. Both were obtained from American Type Culture Collection (Rockville, MD). The MCV strain $\mathrm{JHM}^{24}$ was grown on the mouse tumor cell line $\mathrm{DBT}^{25}$. Both the virus and the cell line used for its propagation were originally obtained from Dr. Stephen Stohlman (University of Southern California, Los Angeles, CA). The cell lines were grown as monolayers in roller bottles using Dulbecco's modified Eagle medium (DMEM)(Gibco BRL, Grand Island, NY) supplemented with $10 \%$ fetal calf serum (FCS) in a humidified cell culture incubator at $37^{\circ} \mathrm{C}$ in an atmosphere of $5 \% \mathrm{CO}_{2}$. Virus infected cell monolayers were cultured at a lower temperature optimal for viral replication $\left(34^{\circ} \mathrm{C}\right)$. Infected cell supernatants were harvested at $18 \mathrm{hr}$ post-infection for JHM and $36 \mathrm{hr}$ post-infection for $229 \mathrm{E}$, with subsequent steps carried out at $4^{\circ} \mathrm{C}$. Virus was purified from infected cell supernatants by precipitation with 
$0.5 \mathrm{M} \mathrm{NaCl}$ and $10 \%$ polyethylene glycol (mw 8,000; Sigma Chemical Co., St. Louis, MO), final concentration, followed by pelleting precipitated material at $10,000 \mathrm{x} g$. The virus was further purified by ultracentrifugation over two separate sucrose gradients, a $30 \% / 50 \%$ discontinuous gradient centrifuged at $25,000 \mathrm{x} g$ at $4^{\circ} \mathrm{C}$ for four hr followed by centrifugation of virus material through a $25 \%-55 \%$ continuous gradient at $25,000 \mathrm{x} g$ for $18 \mathrm{hr}$. The purified virus band was removed from the gradient, pelleted by ultracentrifugation, and resuspended in sterile phosphate buffered saline (PBS) at a concentration of $1 \mathrm{mg} / \mathrm{ml}$. Virus purity was determined by analyzing each preparation by polyacrylamide gel electrophoresis (SDSPAGE) and protein concentrations were determined with the BCA protein assay (Pierce Chemical Co., Rockford, IL). The virus was completely inactivated by exposure to a combination of ultraviolet light (exposed for $15 \mathrm{~min}$ to a 15 watt $300 \mathrm{~nm}$ UV light source placed five $\mathrm{cm}$ from its surface), sonication and gamma irradiation (10,000 rad exposure from a cesium source IBL 437C cell irradiator; CIS-US, Inc., Bedford, MA) prior to being used in antigen presentation assays to prevent its replication in viable cells.

Autologous immortalized human B lines cell used as antigen presenting cells were obtained by transforming peripheral B cells using Epstein Barr virus (EBV). The EBV secreting transformed Marmoset lymphoblastoid cell line, B95-8 (originally obtained from American Type Culture Collection, Rockville, MD), was grown to high density, and the culture supernatant was centrifuged and filtered to remove cellular components. Peripheral blood lymphocytes (PBL) were obtained from heparinized blood by density gradient centrifugation over Histopaque-1077 solution (Sigma Chemical Co., St. Louis, MO). Approximately $1 \times 10^{7} \mathrm{PBL}$ were incubated with $1 \mathrm{ml}$ of EBV containing B95-8 supernatant for $1 \mathrm{hr}$ at $37^{\circ} \mathrm{C}$ in a $10 \% \mathrm{CO}_{2}$ incubator. Cells were washed three times with RPMI 1640 medium (Gibco BRL, Grand Island, NY), resuspended to $2 \times 10^{6}$ cells per $\mathrm{ml}$ and plated into the first two rows of a flat bottomed 96 well plate at $200 \mu \mathrm{l}$ per well. Subsequent rows contained serial two-fold dilutions of these cells. Ten $\mu \mathrm{l}$ of a $10 \mu \mathrm{g} / \mathrm{ml}$ stock of cyclosporin A (a generous gift of Sandoz Pharmaceuticals, East Hanover, NJ) was added to each well to inactivate the $T$ cells in these cultures. The plate was fed weekly, with transformed $B$ lymphoblastoid lines usually arising from three to five weeks after setting up the cultures. B cell lines were expanded as suspension cultures in Iscove's modified Dulbecco's medium (IMDM)(Gibco BRL, Grand Island, NY) supplemented with $5 \times 10^{-5} \mathrm{M}$ 2-mercaptoethanol, $10 \% \mathrm{FCS}, 100 \mathrm{U} / \mathrm{ml}$ penicillin and $100 \mu \mathrm{g} / \mathrm{ml}$ streptomycin.

\section{Isolation of Purified 229E Nucleocapsid (N) and Spike (S) Proteins}

Whole inactivated 229E virus was electrophoresed on 10\% SDS-PAGE gels under reducing conditions. The gels were fixed and stained briefly with Coomassie brilliant blue dye to locate the $\mathrm{N}$ and $\mathrm{S}$ proteins, destained and then rehydrated in distilled water. The protein bands were excised from the gel, minced into $2-3 \mathrm{~mm}^{2}$ pieces and placed into an electro-elution concentrator block (CBS Scientific, Del Mar, CA) in 0.05 M Tris acetate, $0.1 \%$ SDS buffer. Proteins were electrophoretically eluted from gel pieces overnight at 50 V. The buffer in the unit was changed to PBS and electrophoresis continued for two hr prior to harvesting the purified proteins.

\section{Preparation of 229E Specific Human T Cell Clones}

Transformed human B cells were used as antigen presenting cells to generate $229 \mathrm{E}$ specific $\mathrm{T}$ cell lines from autologous $\mathrm{PBL}$. The $\mathrm{B}$ cells were incubated overnight with whole gradient purified $229 \mathrm{E}$ to allow for antigen $(\mathrm{Ag})$ processing to occur, with $1 \times 10^{7} \mathrm{~B}$ cells being incubated with $250 \mu \mathrm{g} \mathrm{229E}$ in $5 \mathrm{ml}$ of fresh X-VIVO 15 medium (Biowhittaker, Walkersville, MD). Cultures containing freshly isolated autologous PBL were set up the 
following day with irradiated (4000 rad) Ag pulsed B cells. PBL were isolated by gradient density centrifugation over Histopaque-1077. The buffy coat layer was transferred and the cells were washed three times in balanced salt solution. The PBL were mixed with the Ag-pulsed B cells resulting in final culture conditions of $5 \times 10^{5} / \mathrm{ml} \mathrm{PBL,} 2 \times 10^{5} / \mathrm{ml} \mathrm{B}$ cells and $5 \mu \mathrm{g} 229 \mathrm{E}$ per well of a 24 well plate, with two plates being used. The cultures were incubated at $37^{\circ} \mathrm{C}$ in a humidified $10 \% \mathrm{CO}_{2}$ atmosphere for a total of ten days, being fed on day five with $1 \mathrm{ml}$ of fresh medium. On day five (and on each day thereafter, up to day ten) eight wells were pooled and viable cells isolated by centrifugation over Histopaque- 1077 . The cells were cultured in fresh medium with 5\% T-stim (contains IL-2, PHA and other T cell growth factors; Collaborative Biomedical Products, Bedford, MA) with $2 \times 10^{5} / \mathrm{ml}$ irradiated B cells as feeders. The cells were cloned in limiting dilution in 96 well plates using X-VIVO 15 medium with $8 \%$ T-stim and $2 \times 10^{4} /$ well irradiated feeder B cells. Remaining bulk culture cells were frozen away for future use. The plates were fed $100 \mu \mathrm{l} /$ well fresh medium with $20 \mathrm{U} / \mathrm{ml}$ recombinant human IL-2 (Collaborative Biomedical Products, Bedford, MA) on day five after cloning, and then fed every 5-6 days with fresh medium containing $8 \%$ T-stim. Wells that showed growth were expanded to $1 \mathrm{ml}$ cultures using the same culture conditions and then tested in antigen proliferation assays five to seven days after expansion.

\section{T Cell Proliferation Assay}

T cells expanded to 24 well plates were tested in an $\mathrm{Ag}$ proliferation assay with $\mathrm{Ag}$ pulsed $B$ cells irradiated just prior to setting up the assay. Generally, $5 \times 10^{3}$ to $1 \times 10^{5}$ viable T cells were cultured with $2 \times 10^{4} \mathrm{~B}$ cells with or without $1 \mu \mathrm{g} /$ well $229 \mathrm{E}$ in flat bottomed 96 well plates in a final volume $200 \mu \mathrm{l}$. After two to three days, proliferation was measured during the final $18 \mathrm{hr}$ of culture by the uptake of $\left[{ }^{3} \mathrm{H}\right]$-thymidine $\left(\left[{ }^{3} \mathrm{H}\right]-\mathrm{TdR}\right)$ and counted in a beta scintillation counter. Those cultures that responded well to whole $229 \mathrm{E}$ virus were reexamined after subcloning in a second proliferation assay with whole JHM virus (1 $\mu \mathrm{g} /$ well) and purified 229E N or S proteins (0.1-0.2 $\mu \mathrm{g} / \mathrm{well})$.

\section{Subcloning of 229E-Specific T Cell Lines}

$\mathrm{T}$ cell lines that showed a proliferative response towards $229 \mathrm{E}$ in the initial screening assay were expanded in fresh medium containing $20 \mathrm{U} / \mathrm{ml}$ human recombinant IL-2 for 3-5 days. The cultures were examined each day and the line was subcloned again in 96 well culture plates when it appeared that growth was optimal. Wells that showed positive growth were again expanded and tested for proliferation to whole $229 \mathrm{E}$, with virus-specific subclones expanded for further study or to freeze down in reserve. Generally, 20 to 30 subclones were generated for each $229 \mathrm{E}$-specific $\mathrm{T}$ cell line. The subclones were used in determining $\mathrm{Ag}$ dose response curves and to test $\mathrm{Ag}$ specific responses to the $\mathrm{N}$ and $\mathrm{S}$ proteins.

\section{RESULTS AND DISCUSSION}

This report describes the characterization of eleven independently isolated 229E-specific human T cell clones derived from two normal healthy donors. The 229E specific clones were obtained after culturing peripheral blood lymphocytes in vitro with virus pulsed APC. We assume that there are CV-specific $\mathrm{T}$ cells circulating in peripheral blood, considering the likelyhood of $\mathrm{CV}$ infections each year. A considerable amount of time was spent working out optimal conditions for the in vitro cultures and $\mathrm{Ag}$ presentation assays. Initially, primary in vitro cultures of $\mathrm{PBL}, \mathrm{APC}$ and $229 \mathrm{E}$ were cloned from seven to fifteen days after onset. 
In some cases after the primary stimulation with virus, cells were given a rest period by culturing in fresh medium with a small amount of growth factors (1\% T-stim) for seven to ten days, followed by restimulation with 229E for an additional week. However, the majority of $229 \mathrm{E}$-specific lines were derived from cells cloned from primary cultures that were five to seven days old (nine out of eleven). In our experience, reexposure of primary cultures to a second round of $229 \mathrm{E}$ stimulation did not increase the probability of generating 229E-specific lines.

The lines were selected on the basis of a high proliferative response to $229 \mathrm{E}$ virus pulsed APC relative to APC alone. Although the proliferative response was quantitated by the uptake of $\left[{ }^{3} \mathrm{H}\right]-\mathrm{TdR}$, lines that responded well showed an obvious difference in the numbers of viable cells, which often appeared as clumps of cell blasts that were discernable by visual inspection alone. Typical responses of the eleven 229E-specific T clones are shown in Figure 1.

Stimulation indices (SI) for these $\mathrm{T}$ cell clones ranged from an SI of 5 (clone 2A.3) to 91 (clone 2C.9-3H.11). Six of the lines were isolated from one individual after screening a total of 558 clones resulting from two separate in vitro cultures, while the remaining five lines were isolated from another individual after screening a total of 410 clones resulting from a single in vitro culture. The frequency of clones isolated that responded well and maintained their response after subcloning corresponds to a $1.1 \%$ and $1.2 \%$ efficiency, respectively, although the actual numbers of clones selected after the initial screening was closer to $5 \%$. Numerous lines that were initially selected based on a stimulation index of three to five were retested or subcloned, but, with one exception, the results of retesting the lines and subclones of marginal responders were uniformly negative. It is unclear whether

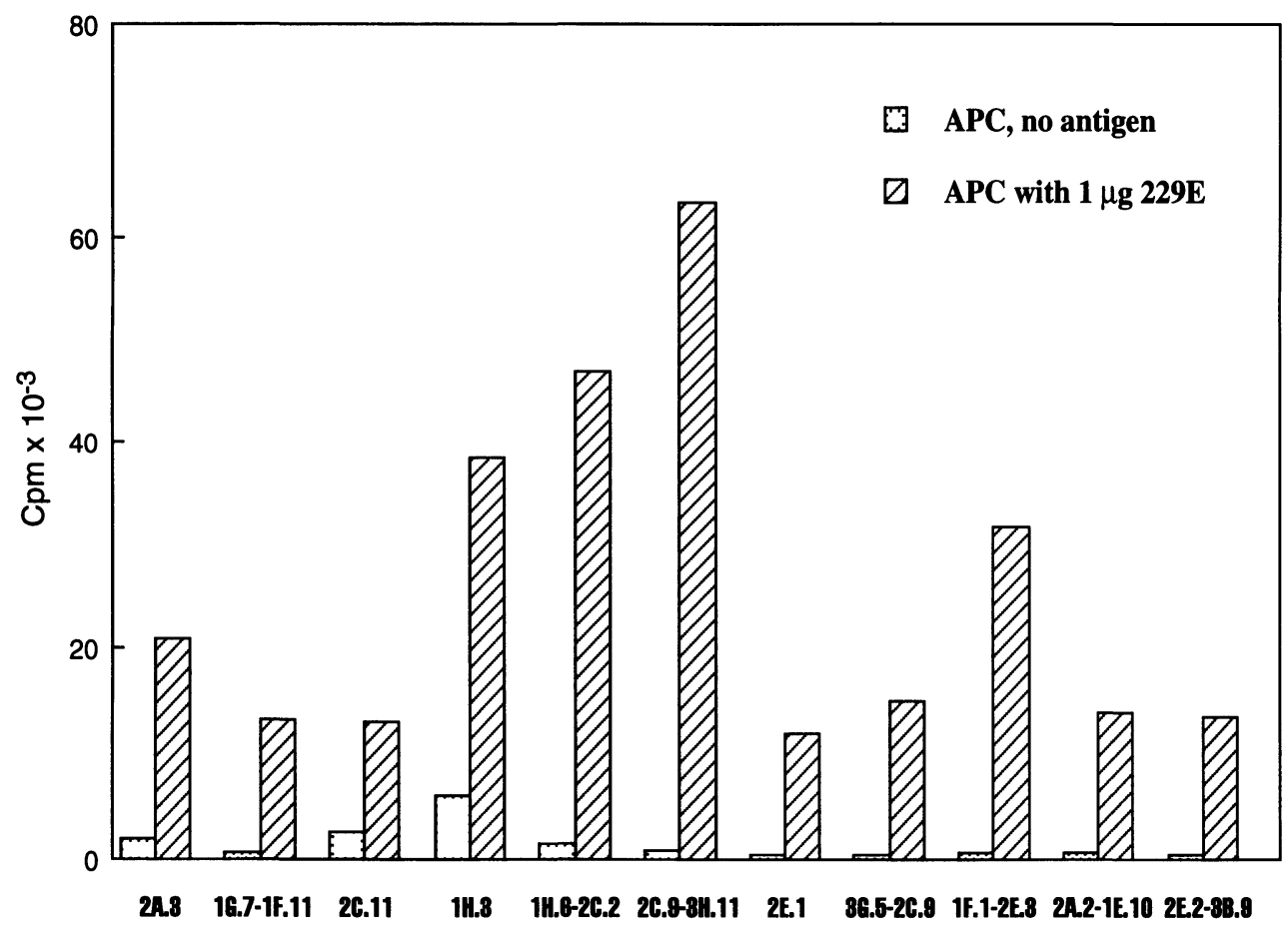

Figure 1. Response of 229E-specific human $\mathrm{T}$ cell clones towards $229 \mathrm{E}$ as detected in an $\mathrm{Ag}$ presentation assay. Approximately $2 \times 10^{3}$ to $1 \times 10^{5} \mathrm{~T}$ cells were cocultured with $2 \times 10^{4}$ autologous irradiated transformed B cells with or without $1 \mu \mathrm{g}$ of inactivated 229E After two to three days, proliferation was measured by the uptake of $\left[{ }^{3} \mathrm{H}\right]-\mathrm{TdR}$ during the final $18 \mathrm{hr}$ period of culture and counted in a beta scintillation counter 


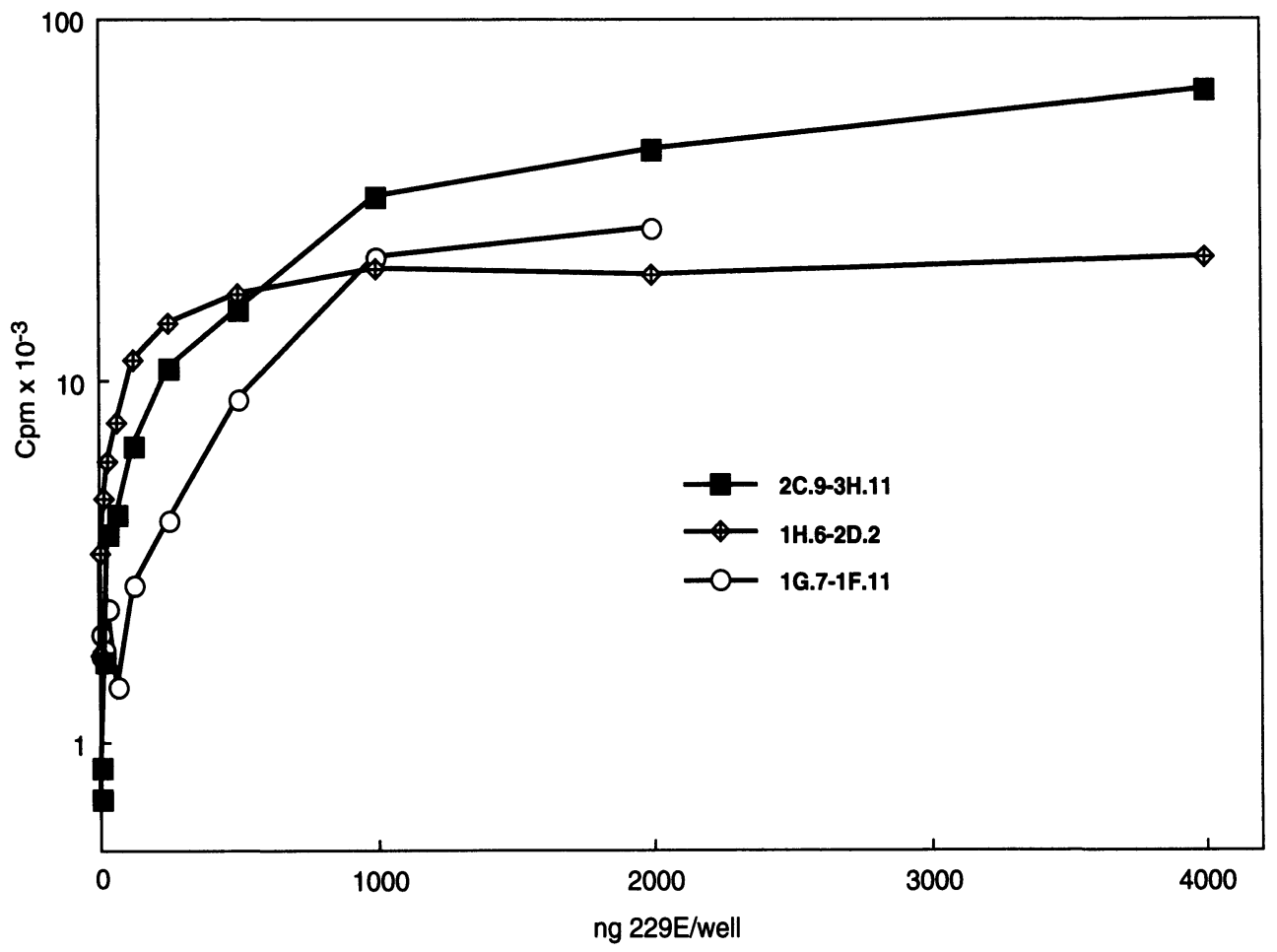

Figure 2. Dose response curve of 229E-specific T cell clones towards varying amounts of 229E. Autologous EBV transformed B cells lines were incubated overnight with serial two-fold dilutions of 229E ranging from $7 \mathrm{ng}$ to $4000 \mathrm{ng}$ per $100 \mathrm{ml}$. Approximately $2 \times 10^{4} \mathrm{Ag}$ pulsed B cells per well were cocultured with T cells in triplicate. The number of viable T cells per well for each subclone was $2.0 \times 10^{4}$ for $1 \mathrm{G} .7-1 \mathrm{~F} .11,2.4 \times 10^{4}$ for 2C.9-3H.11, and $7.5 \times 10^{4}$ for 1H.6-2D.2. Proliferative responses were assessed by the uptake of $\left[{ }^{3} \mathrm{H}\right]-\mathrm{TdR}$.

or not these weak responders consisted of multiple cell lines made up of a minor 229E-specific $\mathrm{T}$ cell population that was overgrown by a nonresponding line(s). All of the $\mathrm{T}$ cell clones characterized in this report are $\mathrm{CD}^{+} \mathrm{T}$ cells, and therefore presumably recognize a processed viral peptide in the context of class II molecules on the APC.

To determine the limits of the response of $229 \mathrm{E}$-specific $\mathrm{T}$ cell clones to antigen, a dose response curve was performed with three separate subclones by varying the concentration of $229 \mathrm{E}$ in the in the cultures from $7 \mathrm{ng}$ to $4 \mu \mathrm{g}$ per well, as illustrated in Figure 2 . The half-maximal response for these subclones occurred with Ag amounts between $0.125 \mu \mathrm{g}$ to $0.5 \mu \mathrm{g}$ of $229 \mathrm{E}$.

To determine the antigen specificity of the T cell clones, 229E N and S proteins were purified from SDS-PAGE gel slices by electroelution as shown in Figure 3.

We also wanted to determine if there was any crossreactivity of $\mathrm{T}$ cell epitopes on the MCV JHM, which is more closely related serologically to the HCV OC43, but is antigenically unrelated to $229 \mathrm{E}^{13,26}$. The proliferative response of six representative $\mathrm{T}$ cell clones against whole virus and purified 229E N and S proteins is shown in Figure 4. As can be seen, three of the subclones tested responded to the $\mathrm{N}$ protein and three others responded to $\mathrm{S}$. All of the $\mathrm{T}$ cell lines tested to date react with either $\mathrm{N}$ or $\mathrm{S}$, indicating that these proteins probably elicit the immunodominant cell mediated responses in man, as had been previously reported for the mouse $\mathrm{e}^{23,27}$. Currently, we are analyzing what peptides from the $\mathrm{N}$ and $\mathrm{S}$ proteins stimulate these 229E-specific T cell clones and what the TCR usage is on these clones. 


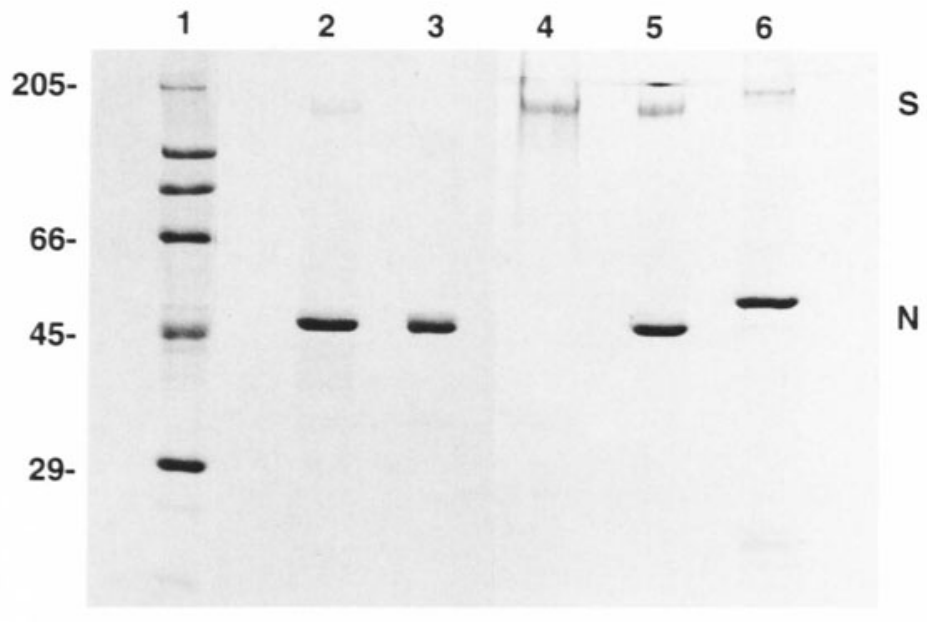

Figure 3. SDS-PAGE analysis of purified whole 229E and JHM coronaviruses and purified electroeluted 229E $\mathrm{N}$ and $\mathrm{S}$ proteins. Lane 1, molecular weight markers with numbers to the left indicating their relative mass in $\mathrm{kDa}$; lanes 2 and 5, whole 229E; lane 3, 229E N protein; lane 4, 229E S protein; and lane 6, whole JHM. Approximately 1-2 $\mu \mathrm{g}$ protein was electrophoresed on a $10 \%$ polyacrylamide gel under reducing conditions. Lanes 1-3 were stained with Coomassie blue dye, while lanes 4-6 were developed using a silver stain to enhance the intensity of the $\mathrm{S}$ protein.

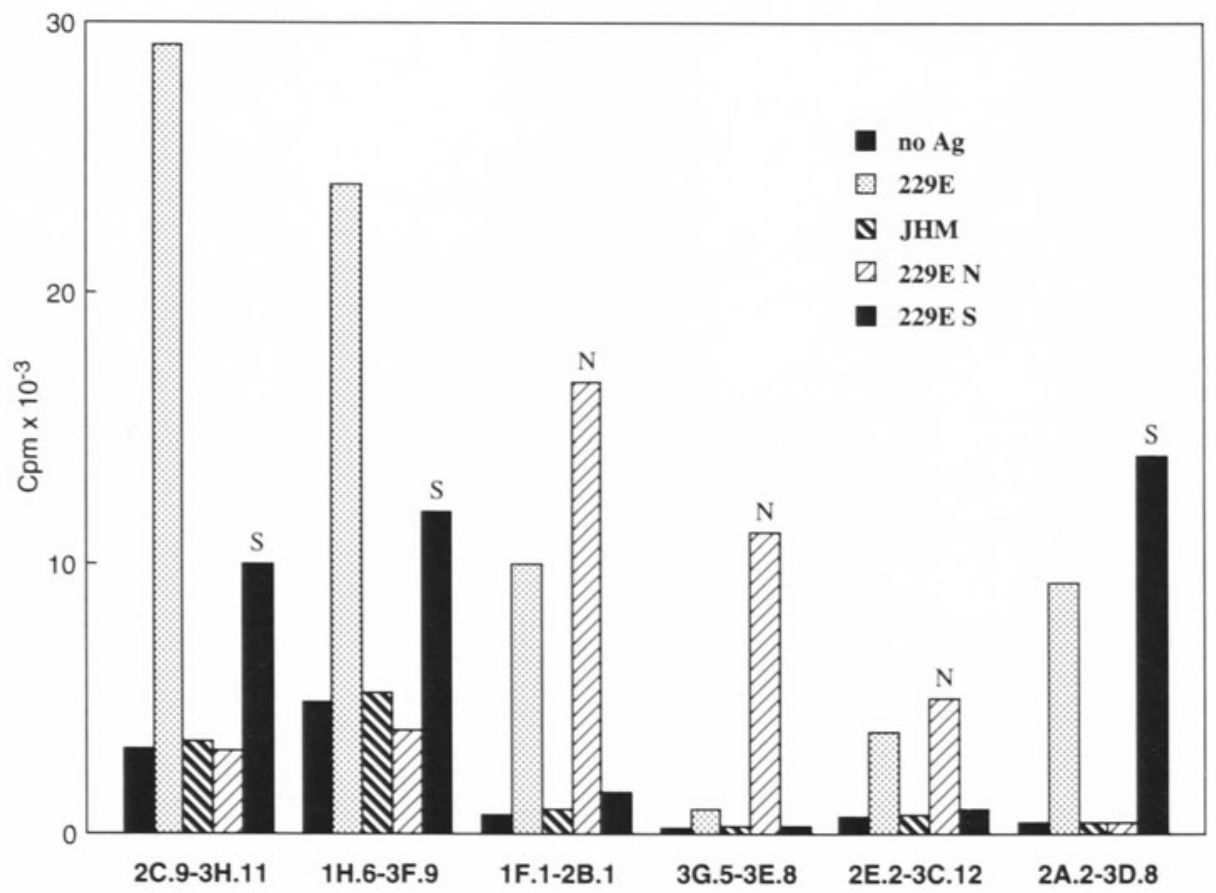

Figure 4. The proliferative response of six representative $229 \mathrm{E}$-specific human $\mathrm{T}$ cell clones to a panel of antigens, including whole $229 \mathrm{E}$ and JHM virus $(2 \mu \mathrm{g} /$ well $)$, and purified $229 \mathrm{E} \mathrm{N}(0.2 \mu \mathrm{g} / \mathrm{well})$ and S $(0.1$ $\mu \mathrm{g} /$ well) proteins. The reactivity patterns were confirmed by testing at least two individual subclones of each $\mathrm{T}$ cell line. The proliferation was determined by measuring the incorporation of $\left[{ }^{3} \mathrm{H}\right]-\mathrm{TdR}$ during the final 18 hr of culture. 
In several autoimmune or chronic inflammatory diseases in man, such as rheumatoid arthritis, insulin-dependent diabetes mellitus, multıple sclerosis, and Lyme disease, T cell mediated immunity is thought to play an important role in the pathogenesis of the disease. $\mathrm{T}$ cells isolated from the target organ involved have frequently been shown to express a restricted set of TCR molecules, supporting the notion that there is a preferential expansion of a subset of pathogenic $\mathrm{T}$ cells responding to an Ag stimulus. Knowing either what the offending antigens are (whether products of viruses or bacteria, or even self proteins) or the receptor usage of $\mathrm{T}$ cells involved in the disease process would allow for a specific target for pharmacologic intervention. In some instances, the putative target Ag and the TCR usage of $\mathrm{T}$ cells isolated from diseased tissue has been determined ${ }^{28-30}$, while in other cases, an association between a particular TCR and an autoimmune disease exists, but the stimulating antigen is unknown ${ }^{31,32}$. The relationship between coronaviruses and MS remains an open question, but it certainly warrants further study.

\section{ACKNOWLEDGMENTS}

This work was supported in part by a grant from the Colorado Neurological Institute to J.S.S., support from Swedish Medical Center, and from the Nancy Davis Foundation. We are grateful to Dr. Judy van de Water (Division of Rheumatology, Allergy and Clinical Immunology, Unıversity of California, Davis, CA) for helpful discussions in generatıng the human 229E-specific T cell lines, and to Joanne Streib (National Jewish Center for Immunology and Respiratory Medicine, Denver, $\mathrm{CO}$ ) for assisting us in generatıng the EBV transformed human B cell lines.

\section{REFERENCES}

1 Zamvil, S S , and L Steınman The T lymphocyte in experımental allergıc encephalomyelitıs Annu Rev Immunol 1990, 8579

2 Acha-Orbea, H, D J Mitchell, L Timmermann, D C Wraith, and G S Tausch Limited heterogeneity of $\mathrm{T}$ cell receptors from lyphocytes mediatıng autoimmune encephalomyelitis allows specific immune intervention Cell 1988, 54263

3 Ben-Nun, A, H Wekerle, and I R Cohen Vaccination against autoımmune encephalomyelitıs with T-lymphocyte line cells reactıve agaınst myelın basic proteın Nature 1981, 29360

4 Martın, R , H F McFarland, and D E McFarlın Immunologic aspects of demyelınatıng diseases Annu Rev Immunol 1992, 10153

5 Booss, J and J H Kım Evidence for a viral etıology of multıple sclerosis In "Handbook of Multıple Sclerosı", S D Cook, ed Marcel_Dekker, Inc, New York 1990, pp 41-61

6 McIntosh, K Coronaviruses In "Virology", B N Fields, et al, eds Raven Press, New York 1985, pp 1323-1330

7 Hamre, D, and M Beem Virologic studies of acute respiratory disease in young adults V Coronavirus 229E infections durıng six years of surveillance Am J Epidemiol 1972, 9694

8 Resta, S, J P Luby, C R Rosenfeld, and J D Siegel Isolation and propagation of a human enteric coronavirus Science 1985, 229978

9 Battaglıa, M , N Passarını, A DiMatteo, and G Gerna Human enterıc coronavıruses further characterization and immunoblottıng of viral proteins J Inf Dis 1987, 155140

10 Malkova, D , J Holubova, J M Kolman, F Lobkovic, L Pohlreichova, and L Zıkmundova Isolatıon of Tettnang coronavirus from man? Acta Virol (Prague)(Eng Ed ) 1980, 24363

11 Tanaka, R, Y Iwasakı, and H J Koprowskı Ultrastructural studies of perıvascular cuffing cells in multiple sclerosis brain J Neurol Sc1 1976, 28121

12 Burks, J S, B L Devald, L D Jankovsky, and J D Gerdes Two coronaviruses isolated from central nervous system tissue of two mulıple sclerosis patients Science 1980, 209933 
13 Gerdes, J C, I Kleın, B L DeVald, and J S Burks Coronavırus isolates SK and SD from multıple sclerosis patients are serologically related to murine coronaviruses A59 and JHM and human coronavirus OC43, but not to human coronavirus 229E J Virol 1981, 38231

14 Murray, R S , B Brown, D A Brian, and G F Cabirac Detection of coronavirus RNA and antigen in multıple sclerosis brain Ann Neurol 1992, 31525

15 Stewart, J N, S Mounır, and P J Talbot Human coronavirus gene expression in the brains of multiple sclerosis patients Virology 1992, 191502

16 Talbot, P J , S Ekande, N R Cashman, S Mounır, and J N Stewart Neurotropısm of human coronavirus 229E In Adv in Exp Med and Biol, H Laude and J-F Vautherot, eds Plenum Press, New York 1993, 342339

17 Murray, R S , G-Y Ca1, K Hoel, J-Y Zhang, K F Soıke, and G F Cabırac Coronavirus infects and causes demyelınation in primate central nervous system Vırology 1992, 188274

18 Flemıng, J O , M D Trowsdale, J Bradbury, S A Stohlman, and L P Weıner Experımental demyelınation induced by coronavirus JHM (MHV-4) Molecular identıfication of a viral paralytic disease Microb Path 1987, 39

19 Wege, H, S G Siddell, and V Ter Meulen The biology and pathogenesis of coronaviruses Curr Top Microbiol Immunol 1982, 99165

20 Nagashıma, K, H Wege, R Meyermann, and V Ter Meulen Demyelınatıng encephalomyelıtıs induced by a long term coronavirus infection in rats Acta Neuropath 1979, 45205

21 Kyuwa, S, and S A Stohlman Pathogenesis of a neurotropic murine coronavirus, strain JHM, in the central nervous system of mice Semin Vir 1990, 1273

22 Williamson, J S P, and S A Stohlman Effective clearance of mouse hepatitis virus from the central nervous system requires both $\mathrm{CD}^{+}$and $\mathrm{CD} 8^{+} \mathrm{T}$ cells $\mathrm{J}$ Virol 1990, 644589

23 Korner, H, A Schiephake, J Winter, F Zımprich, H Lassmann, J Sedgwick, S Siddell, and H Wege Nucleocapsid or spıke proten specific $\mathrm{CD} 4^{+} \mathrm{T}$ lymphocytes protect agaınst coronavirus-induced encephalomyelitis in the absence of $\mathrm{CD}^{+} \mathrm{T}$ cells J Immunol 1991, 1472317

24 Stohlman, S A, and L P Weiner Chronic nervous system demyelınation in mice after JHM virus infection Neurology 1981, 3138

25 Hirano, N, K Fugiwara, S Hino, and M Matumoto Replication and plaque formation of mouse hepatitis virus (MHV-2) in mouse cell line DBT culture Arch Gesamte Virusforsch 1974, 44298

26 Weiss, S Coronavirus SD and SK share extensive nucleotıde homology with murine coronavirus MHV-A59 more than that shared between human and murıne coronaviruses Virology 1983, 126669

27 Bergmann, C , M McMillan, and S Stohlman Characterization of the $L^{\mathrm{d}}$-restricted cytotoxic T-lymphocyte epıtope in the mouse hepatitıs virus nucleocapsid protein J Virol 1993, 677041

28 Oksenberg, J R , M A Panzara, A B Begovıch, D Mitchell, H A Erlıch, R S Murray, R Shımonkevıtz, $\mathrm{M}$ Sherritt, J Rothbard, C C A Bernard, and L Steınman Selection for T-cell receptor $V \beta-D \beta-J \beta$ gene rearrangements with specificity for a myelin basic protein peptide in brain lesions of multiple sclerosis Nature 1993, 36268

29 Wucherpfennıg, K W, K Ota, N Endo, J G Seıdman, A Rosenzweıg, H L Weıner, and D A Hafler Shared human T cell receptor usage to immunodomınant regions of myelın basic protein Science 1990, 2481016

30 Lahesmaa, R, M-C Shanafelt, A Allsup, C Soderberg, J Anzola, V Freıtas, C Turck, L Steınman, and G Peltz Preferential usage of $\mathrm{T}$ cell antigen receptor V region gene segment V $\beta 51$ by Borrelia burgdorfer antigen-reactive T cell clones isolated from a pattent with Lyme disease J Immunol 1993, 1504125

31 Palıard, X, S G West, J A Lafferty, J R Clements, J W Kappler, P Marrack, and B L Kotzın Evıdence for the effects of a superantigen in rheumatoid arthritıs Science 1991, 253325

32 Conrad, B, E Weidmann, G Trucco, W A Rudert, R Behboo, C Ricordı, H Rodriquez-Rılo, D Finegold, and $\mathrm{M}$ Trucco Evidence for superantigen involvement in insulin-dependent diabetes mellitus aetiology Nature 1994, 371351 